\title{
Sistem Pendukung Keputusan Penentuan Status Karyawan Menggunakan Metode Naïve Bayes
}

\author{
Decision Support System for Determining Employee Status Using Nä̈ve Bayes Method \\ Andri Firmansyah*1, Feri Ramadhani' ${ }^{2}$, Edri Fauzan ${ }^{3}$ \\ 1,2,3 Program Studi Teknik Informatika, Fakultas Teknik, Universitas Pelita Bangsa Bekasi \\ e-mail: *11andrifirmansyah@ pelitabangsa.ac.id, ${ }^{2}$ feriramdhani39@gmail.com, ${ }^{3}$ edri@edri.us
}

\begin{abstract}
Abstrak
Dalam penelitian ini dirumuskan masalah tentang bagaimana mengimplementasikan metode naïve bayes dalam menentukan keputusan status karyawan, dengan tujuan dapat mempercepat dan mempermudah pengambilan keputusan dalam menentukan status karyawan magang menjadi karyawan kontrak pada PT EMSONIC INODONESIA. Metode naïve bayes menggunakan kriteria-kriteria karyawan sebagai data training, dan menghitung data tersebut untuk medapatkan nilai probabilitasnya sehingga dengan nilai probabilitas tersebut dapat memprediksi hasil keputusan apakah seorang karyawan layak atau tidak diubah statusnya. Dalam membangun sistem pendukung keputusan penentu status karyawan digunakan visual studio 2010, dan juga menggunakan MySql sebagai database untuk menyimpan data-data yang digunakan. Hasil dari sistem pendukung keputusan menggunakan metode naïve bayes terbukti dapat memprediksi dengan tepat kelayakan status karyawan.
\end{abstract}

Kata kunci-SPK, nä̈ve bayes, status karyawan

\begin{abstract}
In this study, the problem was formulated about how to apply the naïve bayes method in determining employee status decisions, with the aim of accelerating and ease decision making in determining from apprenticeship status to contract status employees at PT EMSONIC INODONESIA. The naïve bayes method uses employee criteria as training data, and calculates data to get its probability value so that the probability value can predict the outcome of the decision whether the employee meets the requirements or does not change status. In building a decision support system for determine employee status, visual studio 2010 was used, and also used MySql as a database to store the data used. The results of the decision support system using the naïve bayes method are proven to be able to predict the advisability of employee status.
\end{abstract}

Keywords—dss, naïve bayes, employee status,

\section{PENDAHULUAN}

Perubahan status karyawan magang menjadi karyawan kontrak adalah agenda rutin yang di laksanakan oleh perusahaan, untuk pengembangan karir pegawai magang selama masa perjanjian. Seleksi calon karyawan kontrak di lakukan ketika masa perjanjian magang habis dimana karyawan magang berhak dipromosikan menjadi karyawan kontrak. Kriteria yang digunakan untuk menentukan apakah seorang pegawai layak atau tidak untuk menjadi karyawan kontrak yakni absensi, skill, kepribadian, prestasi, dan lain-lain. Dengan penilaian dari kriteria tersebut, perusahan dapat mempertimbangkan serta memberi keputusan layak atau tidaknya seorang karyawan magang menjadi karyawan kontrak. Namun kriteria-kriteria tersebut tidak memiliki nilai yang baku sehingga sulit menjadi tolak ukur, padahal suatu kriteria dapat menjadi lebih penting dari kriteria yang lain dengan berbagai pertimbangan oleh perusahaan.

Pegawai yang berkualitas tentu saja dapat memberikan hal yang positif bagi perusahaan. Oleh sebab itu perusahaan harus dapat menyeleksi pegawainya dengan baik, agar mendapat orang yang mampu bekerja secara optimal dalam melaksanakan suatu pekerjaan. Dalam proses

Informasi Artikel:

Submitted: Juli 2020, Accepted: September 2020, Published: November 2020

ISSN: 2685-4902 (media online), Website: http://jurnal.umus.ac.id/index.php/intech 
seleksi karyawan perusahaan harus benar-benar membuat peraturan yang ketat dengan melihat karakteristik karyawan magangnya. Di PT EMSONIC sering terjadi kesalahan dalam menilai karyawan magang yang akan diubah statusnya menjadi karyawan kontrak, seperti masih kurangnya pengetahuan pekerjaan, banyaknya absen, kepribadian yang tidak baik, kurangnya kesadaran kerja, dan tidak memiliki inovasi. Salah satu metode yang dapat membantu dalam masalah ini adalah dengan menggunakan metode data mining atau metode algoritma Nä̈ve Bayes.

Algoritma Nä̈ve Bayes Classifer merupakan salah satu perhitungan probablitias yang dapat menghitung dan memprediksi keanggotaan suatu kelas [1]. Pada kelas klasifikasi, naïve bayes memiliki akurasi yang tinggi melalui perhitungan sederhana yang dilakukannya[2]. Dan hal ini tentu saja menjadi salah satu keunggulan metode Nä̈ve Bayes yang hanya membutuhkan jumlah data pelatihan (data training) yang kecil untuk menentukan estimasi parameter yang di perlukan dalam proses pengklasifikasian. Karena yang diasumsikan sebagai variabel independent, maka hanya varians dari suatu variabel dalam sebuah kelas yang dibutuhkan untuk menentukan klasifikasi, bukan keseluruhan dari matriks kovarians. Oleh sebab itu metode Nä̈ve Bayes digunakan sebagai algoritma pada penelitian ini. Data karyawan yang bekerja akan digunakan sebagai data training untuk memprediksi pengalihan status karyawan kontrak dan mengetes tingkat keberhasilan prediksi tersebut menggunakan data testing terhadap karyawan yang masih berstatus magang.

Naïve bayes pernah diterapkan untuk melakukan klasifikasi data pendaftar beasiswa PPA di Universitas AMIKOM Yogyakarta apakah layak mendapatkan beasiswa tersebut ataukah tidak, berdasarkan hasil pengujiannya maka didapatkan bahwa semakin besar prosentase akurasi yang dihasilkan oleh naïve bayes maka semakin banyak pula data yang diperlukan dalam proses pengujiannya[3]. Naïve bayes juga pernah digunakan untuk menentukan besarnya insentif bulanan yang harus diberikan Perusahaan Jasa kepada karyawan sesuai dengan kinerjanya dalam mengantarkan pesanan berdasarkan rekomendasi para customer [4]. Dalam bidang akademis, naïve bayes juga pernah digunakan untuk memprediksi penilaian mahasiswa terhadap pelayanan akademis pada Perguruan Tinggi, hasil pengujiannya menunjukkan bahwa nilai akurasi, precission dan recall yang dihasilkan oleh algoritma ini cukup tinggi yaitu diatas $95 \%$ hal ini membuktikan bahwa naïve bayes mampu memprediksi dengan baik [5]. Naïve bayes pun pernah digunakan untuk pendeteksian malware melalui diskritisasi variable min max 3 interval dan 5 interval pada atribut kontinu, dimana nilai akurasi yang dihasilkan akan semakin tinggi yaitu 79,7\% dengan prediksi malware 81,29\%[6].

\section{METODE PENELITIAN}

\section{Sistematika penelitian}

Dalam tahap analisis kebutuhan langkah awal peneliti akan melakukan identifikasi masalah melalui proses perubahan status karyawan magang menjadi karyawan kontrak di PT Emsonic Indonesia yang dilakukan oleh HRD berdasarkan data pada kriteria absensi, kemampuan karyawan (skill), penilaian leader, dan pelanggaran yang terjadi. Selanjutnya sistem akan menghitung data tersebut berdasarkan naïve bayes. Yang kemudian akan dilakukan uji coba (testing) berdasarkan fungsionalitas sistem ataupun akurasi yang dihasilkan oleh sistem melalui prosentase akurasi, recall dan precission. Adapun gambaran mengenai sistematika rinci mengenai alur penelitian yang dilakukan terlihat pada Gambar 1. 


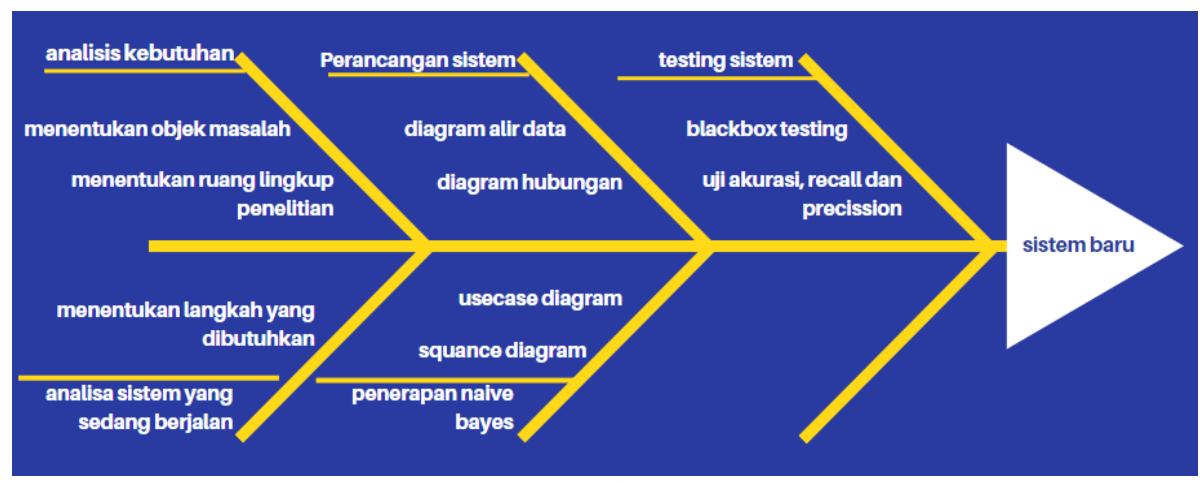

Gambar 1. Sistematika

\section{Naïve bayes}

Naïve bayes merupakan salah satu metode klasifikasi yang manfaatkan probabilitas sederhana melalui likehood maksimum terhadap masing-masing kelasnya [7]. Persamaan dari teorema bayes tersebut adalah[8]:

$P(H \mid X)=\frac{P(X \mid H) \cdot P(H)}{P(X)}$

rumus (1)

Dimana :

$\mathrm{X} \quad$ : data dengan class yang belum diketahui

$\mathrm{H} \quad$ : hipotesis data yang merupakan suatu class spesifik

$\mathrm{P}(\mathrm{H} \mid \mathrm{X}) \quad$ : probabilitas hipotesis $\mathrm{H}$ berdasarkan kondisi X (posteriori probabilitas)

$\mathrm{P}(\mathrm{H}) \quad$ : probabilitas hipotesis $\mathrm{H}$ (prior probabilitas)

$\mathrm{P}(\mathrm{X} \mid \mathrm{H}) \quad$ : Probabilitas $\mathrm{X}$ berdasarkan kondisi hipotesis $\mathrm{H}$

$\mathrm{P}(\mathrm{X}) \quad$ : Probabilitas X

Sedangkan dalam mencari dan menentukan kelas yang cocok untuk sample yang digunakan dilakukan dengan menghitung rumus 2

$P\left(C \mid F_{1} \ldots F_{n}\right)=\frac{P(C) \cdot P\left(F_{1} \ldots F_{n} \mid C\right)}{P\left(F_{1} \ldots F_{n}\right)}$

rumus (2)

Dimana variable $C$ tersebut adalah representasi suatu class sedangkan $F_{1} \ldots F_{n}$ merupakan karakterisktik petunjuk dalam melakukan klasifikasi[8]. Karena $\mathrm{C}$ adalah posterior peluang munculnya kelas $\mathrm{C}$ prior yang akan dikali dengan karakteristik kelas $\mathrm{C}$ (likehood) dan dibagi dengan evidence maka rumus 2 dapat ditulis dengan[9]:

posteriror $=\frac{\text { prior } x \text { likehood }}{\text { evidence }}$

rumus (3)

Dalam penelitian ini, alur dari naïve yang diterapkan terangkum pada Gambar 2. Pada awal sistem akan memilih antara data training dan data testing yang digunakan, selanjutnya sistem akan membaca data training tersebut, dimana jika data tersebut bersifat numerik maka sistem akan menghitung rata-rata (mean) dan standar deviasi untuk setiap parameter yang digunakan namun jika data tersebut bukan bersifat numerik, maka sistem akan menghitungnya secara probabilitas dan menghasilkan table probabilitas. Table dari standar deviasi dan probabilitas tersebut merupakan solusi / hasil yang ditawarkan melalui naïve bayes. 


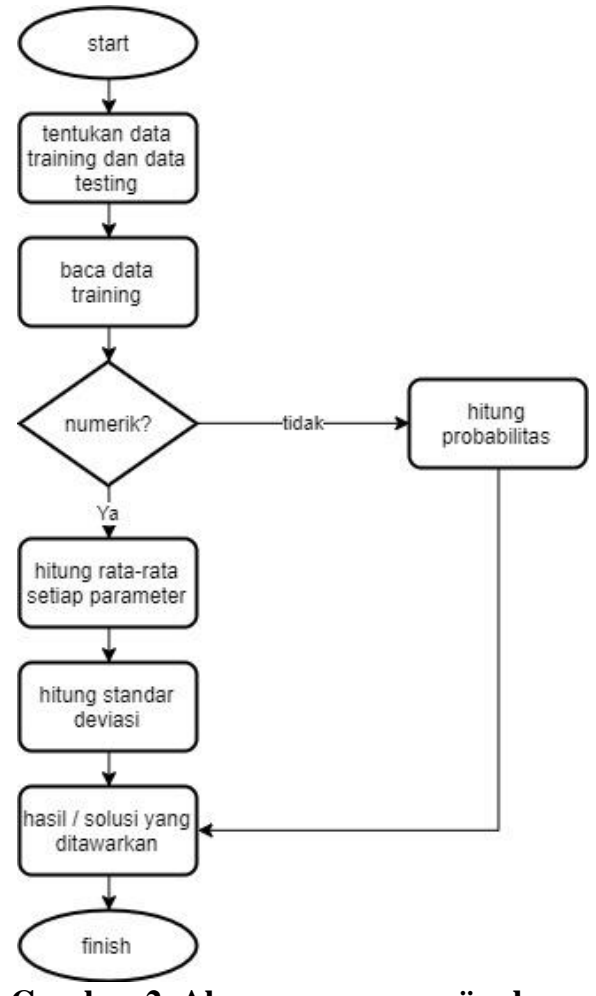

Gambar 2. Alur penerapan naïve bayes

\section{HASIL DAN PEMBAHASAN}

Penelitian ini akan menggunakan 4 variable yaitu absensi, skill, penilaian leader, dan pelanggaran. Dari 4 variable tersebut selanjutnya akan dibentuk 3 himpunan menjadi baik, cukup dan kurang. Rincian mengenai jenis variable dan himpunan yang terbentuk terangkum pada Tabel 1.

Table 1. Variable dan himpunan yang terbentuk

\begin{tabular}{cll}
\hline No & Nama variable & \multicolumn{1}{c}{ Himpunan } \\
\hline 1 & Absensi & $0:$ Baik \\
& & $1-2:$ Cukup \\
& & $>3:$ Kurang \\
\hline 2 & Skill / kompetensi & $>3:$ Baik \\
& & $1-2:$ Cukup \\
& & 0 : Kurang \\
\hline 3 & Penilaian leader & $>90$ : Baik \\
& & $80-89:$ Cukup \\
& & $<80$ : Kurang \\
\hline 4 & Pelanggaran / sanksi & $0:$ Baik \\
& & $1:$ Cukup \\
& & $>1:$ Kurang \\
\hline
\end{tabular}

Untuk sample data training peneliti menggunakan 105 data, rangkuman mengenai sample data tersebut terangkum pada Tabel 2.

Table 2. Sample data

\begin{tabular}{cccccccc}
\hline No & NIK & Yayasan & Absensi & Skill & Penilaian & Pelanggaran & Status \\
\hline 1 & MCN016021 & CN & Baik & Baik & Baik & Baik & Ok \\
\hline 2 & MCN016022 & CN & Baik & Cukup & Cukup & Baik & Ok \\
\hline
\end{tabular}




\begin{tabular}{cccccccc}
\hline 3 & MCN016023 & CN & Baik & Baik & Baik & Baik & Ok \\
\hline 4 & MCN016024 & CN & Baik & Baik & Cukup & Baik & Ok \\
\hline 5 & MCN016053 & CN & Kurang & Kurang & Kurang & Kurang & Gagal \\
\hline 6 & MCN016025 & CN & Kurang & Kurang & Kurang & Kurang & Gagal \\
\hline 7 & MCN016026 & CN & Baik & Baik & Baik & Baik & Ok \\
\hline 8 & MCN016027 & CN & Baik & Baik & Baik & Baik & Ok \\
\hline 9 & MCN016028 & CN & Baik & Baik & Baik & Baik & Ok \\
\hline 10 & MCN016029 & CN & Baik & Cukup & Baik & Baik & Ok \\
\hline$\ldots$ & $\ldots$. & $\ldots$. & $\ldots$. & $\ldots$. & $\ldots$. & $\ldots$. & $\ldots$. \\
\hline 105 & MIS017057 & Insko & Baik & Cukup & Baik & Baik & Ok \\
\hline
\end{tabular}

Selanjutnya akan dilakukan perbandingan antara data uji dari data training. Table 3 adalah rangkuman mengenai hasil perbandingan data uji yang dilakukan.

Table 3. Data uji perbandingan

\begin{tabular}{ccccccc}
\hline \multicolumn{7}{c}{ Hitung $\mathbf{P}\left(\mathbf{X}_{\mathbf{k}} \mid \mathbf{C}_{\mathbf{i}}\right)$ untuk setiap kelas i } \\
\hline Absensi & Ok & Gagal & Ok & Gagal & Nilai Ok & Nilai Gagal \\
\hline Baik & 67 & 7 & $67 / 83$ & $7 / 22$ & 0,807 & 0,318 \\
\hline Cukup & 16 & 6 & $16 / 83$ & $6 / 22$ & 0,193 & 0,273 \\
\hline Kurang & 0 & 9 & $0 / 83$ & $9 / 22$ & 0.000 & 0,409 \\
\hline Skill & Ok & Gagal & Ok & Gagal & Nilai Ok & Nilai Gagal \\
\hline Baik & 55 & 13 & $55 / 83$ & $13 / 22$ & 0,663 & 0,591 \\
\hline Cukup & 28 & 3 & $28 / 83$ & $3 / 22$ & 0,337 & 0,136 \\
\hline Kurang & 0 & 6 & $0 / 83$ & $6 / 83$ & 0,000 & 0,273 \\
\hline Penilaian & Ok & Gagal & Ok & Gagal & Nilai Ok & Nilai Gagal \\
\hline Baik & 76 & 11 & $76 / 83$ & $11 / 22$ & 0,916 & 0,500 \\
\hline Cukup & 7 & 3 & $7 / 83$ & $3 / 22$ & 0,084 & 0,136 \\
\hline Kurang & 0 & 8 & $0 / 83$ & $8 / 22$ & 0,000 & 0,364 \\
\hline Pelanggaran & Ok & Gagal & Ok & Gagal & Nilai Ok & Nilai Gagal \\
\hline Baik & 72 & 9 & $72 / 83$ & $9 / 22$ & 0,867 & 0,409 \\
\hline Cukup & 11 & 3 & $11 / 83$ & $3 / 22$ & 0,133 & 0,136 \\
\hline Kurang & 0 & 10 & $0 / 83$ & $10 / 22$ & 0,000 & 0,455 \\
\hline
\end{tabular}

Kemudian akan dihitung perbandingan untuk setiap kelasnya, table 4 merupakan hasil rangkuman mengenai uji perbandingan setiap kelasnya.

Table 4. Data uji perbandingan setiap kelas

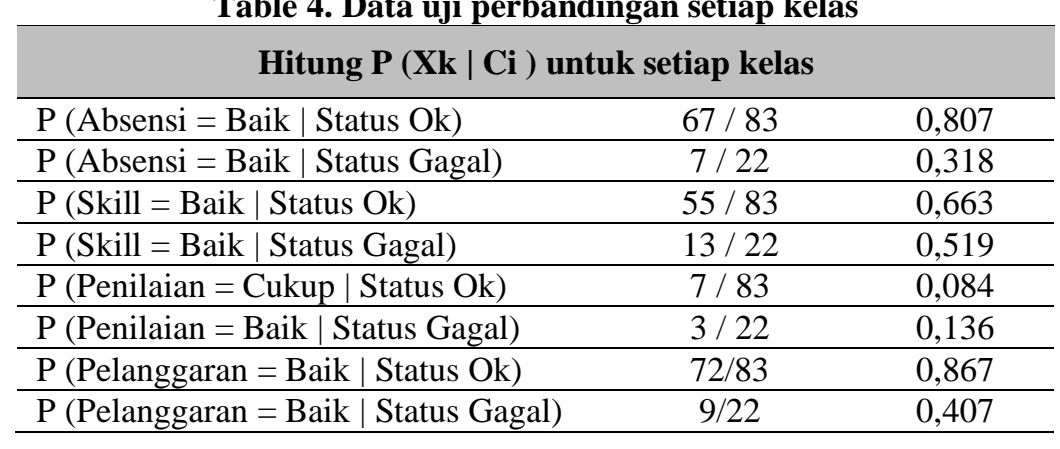

Selanjutnya akan dihitung nilai $\mathrm{P}\left(\mathrm{X} \mid \mathrm{C}_{\mathrm{i}}\right)$ melalui perkalian hasil seluruh nilai perbandingannya. Hasil perhitungannya terlihat seperti:
1. $\mathrm{P}(\mathrm{X} \mid$ Status $=$ "Ok") $=(0,807 \times 0,663 \times 0,084 \times 0,867)$

$$
=0,03915
$$
2. $\mathrm{P}(\mathrm{X} \mid$ Status $=$ "Gagal” $)=(0,318 \times 0,591 \times 0,136 \times 0,409)$

$$
=0,01049
$$


Setelah mengetahui nilai $\mathrm{P}(\mathrm{X} \mid \mathrm{Ci})$ maka nilai tersebut kemudian akan dikalikan dengan nilai $\mathrm{P}\left(\mathrm{C}_{\mathrm{i}}\right)$.

$$
\begin{aligned}
\text { 1. } \mathrm{P}(\mathrm{X} \mid \text { Status }=\text { "Ok") }) \mathrm{P}(\text { Status }=\text { "Ok" }) & =0,03915 \times(83 / 105) \\
& =0,03095 \\
\text { 2. } \mathrm{P}(\mathrm{X} \mid \text { Status = "Gagal") }) \mathrm{P}(\text { Status }=\text { "Gagal" }) & =0,01049 \times(22 / 105) \\
& =0,00219
\end{aligned}
$$

Berdasarkan hasil diatas, maka X (MCN016021) memiliki kelas yang berstatus "Ok" karena nilai dari status ok lebih besar bila dibandingkan dengan nilai status gagal yaitu 0,03095

\section{Implementasi}

Pada bagian ini akan menampilkan GUI dari sistem yang dibuat, tujuannya sebagai perbandingan pada proses pengujian secara blackbox yang akan dilakukan. GUI untuk sistem yang dibuat terdapat pada Gambar 3. Pada form login pengguna diminta untuk memasukkan uername dan password untuk masuk kedalam sistem.

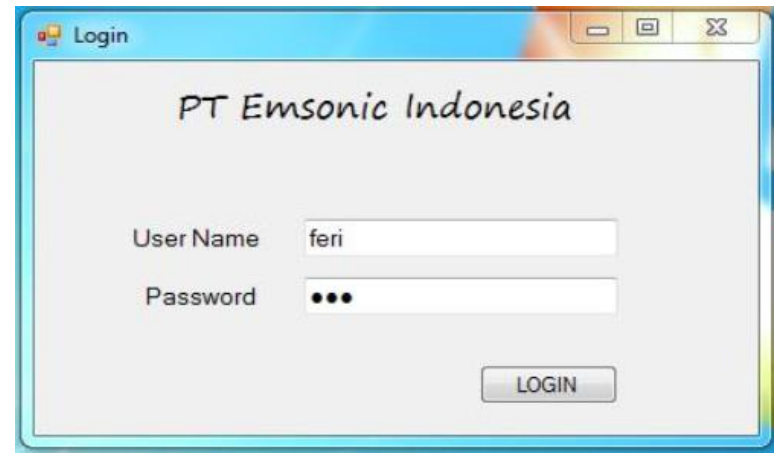

Gambar 3. Form login sistem

Setelah berhasil login, maka sistem akan menampilkan menu utama aplikasi yang memiliki menu data pengguna, data training, data testing dan analisa hasil. Gambar 4 merupakan GUI untuk menu data training. Menu data training digunakan untuk melakukan perhitungan naïve bayes sesuai data yang ada.

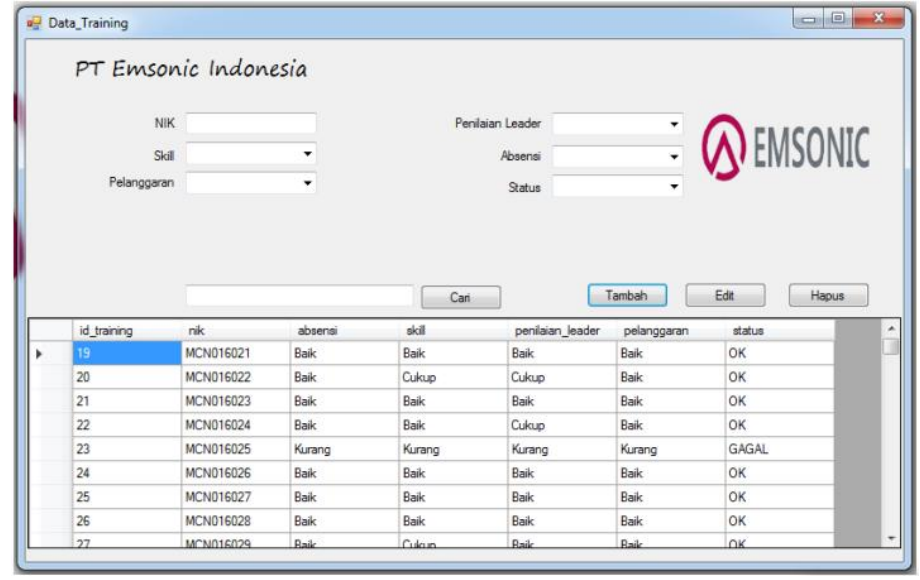

Gambar 4. Menu data training

Sedangkan gambar 5 merupakan GUI untuk data testing, dimana data testing digunakan untuk mengelola data yang akan diuji untuk mengetahui hasil dari status dari data testing tersebut, pengujian yang dilakukan melalui form analisa. 


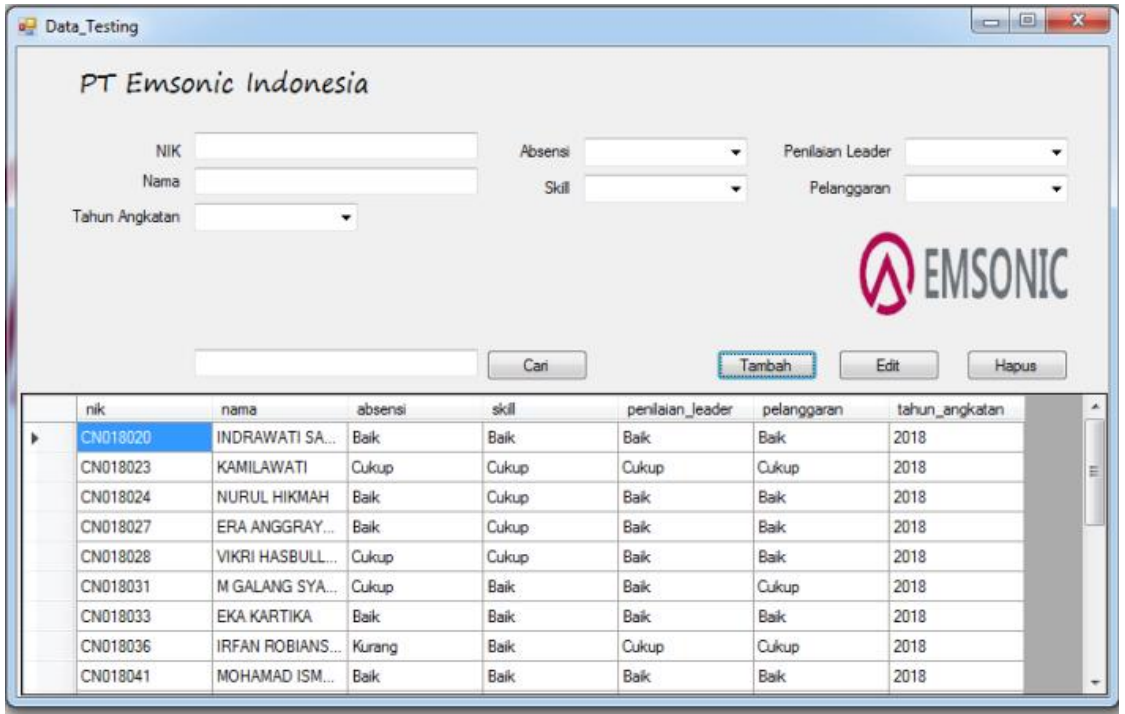

Gambar 5. Menu data testing

Sedangkan gambar 6 merupakan GUI untuk hasil analisa algoritma naïve bayes. Data yang diinput pada form data testing akan diuji menggunakan data yang ada pada data training. Hasil uji tersebut ditampilkan pada form analisa.

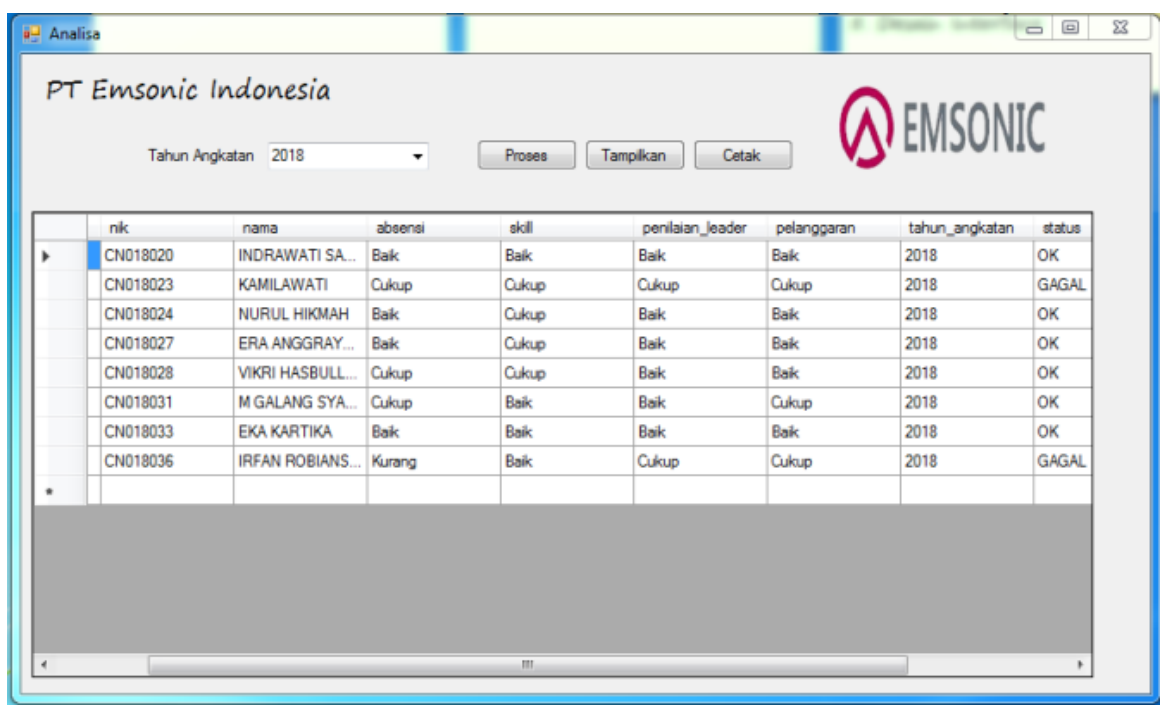

Gambar 6. Menu analisa

\section{Pengujian}

Pengujian dilakukan melalui beberapa skenario untuk mengetahui apakah hasil dari sistem telah sesuai dengan perancangan yang telah dibuat sebelumnya. Adapun hasil pengujian yang dilakukan terangkum pada Tabel 5 .

Table 5. Skenario pengujian sistem

\begin{tabular}{cllll}
\hline No & \multicolumn{1}{c}{ Data masukkan } & \multicolumn{1}{c}{ Hasil diharapkan } & \multicolumn{1}{c}{ Pengamatan } & Kesimpulan \\
\hline 1 & $\begin{array}{l}\text { Username dan password } \\
\text { benar }\end{array}$ & Masuk ke menu utama & $\begin{array}{l}\text { Login berhasil dan } \\
\text { sistem masuk ke menu } \\
\text { utama }\end{array}$ & Valid \\
\hline 2 & $\begin{array}{l}\text { Username dan password } \\
\text { salah ataupun kosong }\end{array}$ & $\begin{array}{l}\text { Menampilkan peringatan } \\
\text { kesalahan dan tetap pada } \\
\text { form login }\end{array}$ & Login gagal & Valid \\
\hline
\end{tabular}




\begin{tabular}{|c|c|c|c|c|}
\hline 3 & $\begin{array}{l}\text { Mengisi seluruh textbox } \\
\text { kemudian mengklik } \\
\text { "tambah" }\end{array}$ & Data training bertambah & $\begin{array}{l}\text { Muncul informasi, data } \\
\text { berhasil ditambah }\end{array}$ & Valid \\
\hline 4 & $\begin{array}{l}\text { Mengisi sebagian textbox } \\
\text { kemudian mengklik } \\
\text { "tambah" }\end{array}$ & $\begin{array}{l}\text { Data training tidak } \\
\text { bertambah }\end{array}$ & $\begin{array}{l}\text { Muncul informasi isi } \\
\text { semua form, data gagal } \\
\text { bertambah }\end{array}$ & Valid \\
\hline 5 & $\begin{array}{l}\text { Mengklik salah satu isi } \\
\text { gridview kemudian } \\
\text { mengubah isi textbox, } \\
\text { dan mengklik "edit" }\end{array}$ & $\begin{array}{l}\text { Data } \\
\text { berhasil di ubah }\end{array}$ & $\begin{array}{l}\text { Muncul } \\
\text { peringatan } \\
\text { memilih } \\
\text { maka } \\
\text { berubah } \\
\end{array}$ & Valid \\
\hline 6 & $\begin{array}{lrr}\text { Mengisi } & \text { textbox } & \text { cari } \\
\text { sesuai } & \text { dengan } & \text { nik, } \\
\text { kemudian } & \text { mengklik } \\
\text { "cari" } & & \end{array}$ & $\begin{array}{lrr}\text { Mengisi } & \text { textbox } & \text { cari } \\
\text { sesuai } & \text { dengan } & \text { nik, } \\
\text { kemudian } & \text { mengklik } \\
\text { "cari" } & \end{array}$ & $\begin{array}{l}\text { Mengisi textbox cari } \\
\text { sesuai dengan nik, } \\
\text { kemudian mengklik } \\
\text { "cari" }\end{array}$ & Valid \\
\hline 7 & $\begin{array}{lrr}\text { Memilih salah } & \text { satu isi } \\
\text { dari } & & \text { gridview } \\
\text { kemudian } & & \text { mengklik } \\
\text { "hapus" } & & \end{array}$ & 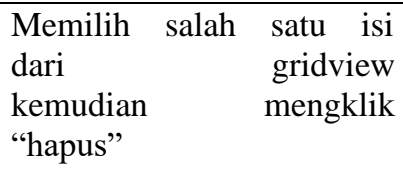 & $\begin{array}{lr}\begin{array}{l}\text { Memilih salah } \\
\text { dari }\end{array} & \text { satu isi } \\
\text { gridview } \\
\text { kemudian } \\
\text { "hapus" }\end{array}$ & Valid \\
\hline 8 & $\begin{array}{lr}\text { Mengisi } & \text { seluruh } \\
\text { textbox } & \text { kemudian } \\
\text { mengklik "tambah" }\end{array}$ & $\begin{array}{l}\text { Data } \\
\text { bertambah }\end{array}$ & $\begin{array}{l}\text { Muncul } \\
\text { informasi, data } \\
\text { berhasil di tambah }\end{array}$ & Valid \\
\hline 9 & $\begin{array}{l}\text { Mengisi } \quad \text { sebagian } \\
\text { textbox kemudian } \\
\text { mengklik "tambah" }\end{array}$ & $\begin{array}{l}\text { Data testing } \\
\text { bertambah }\end{array}$ & \begin{tabular}{lr}
\multicolumn{2}{l}{ Muncul informasi } \\
isi semua & form, \\
data & gagal \\
bertambah &
\end{tabular} & Valid \\
\hline 10 & $\begin{array}{lr}\text { Muncul } & \text { informasi } \\
\text { isi semua } & \text { form, } \\
\text { data } & \text { gagal } \\
\text { bertambah } & \end{array}$ & $\begin{array}{l}\text { Data } \\
\text { berhasil di ubah }\end{array}$ & $\begin{array}{l}\text { Muncul } \\
\text { peringatan } \\
\text { memilih jika } \\
\text { maka dyes" } \\
\text { berubah }\end{array}$ & Valid \\
\hline 11 & $\begin{array}{lrr}\text { Mengisi } & \text { textbox } & \text { cari } \\
\text { sesuai } & \text { dengan } & \text { nik, } \\
\text { kemudian } & \text { mengklik } \\
\text { "cari" } & \end{array}$ & $\begin{array}{l}\text { Menampilkan } \\
\text { sesuai dengan } \\
\text { dari textbox cari }\end{array}$ & $\begin{array}{lr}\text { Menampilkan } & \text { data } \\
\text { sesuai dengan } & \text { isi } \\
\text { dari textbox cari } & \end{array}$ & Valid \\
\hline 12 & 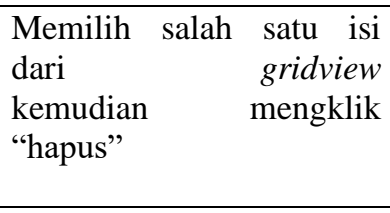 & $\begin{array}{l}\text { Data yang } \\
\text { dari } \\
\text { terhapus }\end{array}$ & $\begin{array}{l}\text { Menampilkan } \\
\text { tombol peringatan } \\
\text { jika di klik "yes" } \\
\text { maka data testing } \\
\text { terhapus }\end{array}$ & Valid \\
\hline 13 & $\begin{array}{l}\text { Memilih } \\
\text { angkatan, } \\
\text { mengklik "proses" }\end{array}$ & $\begin{array}{lr}\text { Memilih } & \text { tahun } \\
\text { angkatan, } & \text { kemudian } \\
\text { mengklik "proses" }\end{array}$ & $\begin{array}{lr}\text { Data } & \text { testing } \\
\text { muncul } & \text { disertai } \\
\text { dengan } & \text { hasil } \\
\text { pengujian } & \text { sesuai } \\
\text { dengan } & \text { tahun } \\
\text { angkatan } & \text { yang } \quad \text { di } \\
\text { pilih } & \\
\end{array}$ & Valid \\
\hline
\end{tabular}

Setelah dilakukan pengujian secara blackbox, maka selanjutnya penulis akan melakukan analisa perbandingan dengan perhitungan manual. Table 6 merupakan hasil perbandingan pengujian yang dilakukan. Untuk prosentase perbandingan hasil pengujian yang dilakukan dapat dihitung dengan cara:

hasil pengujian $=\frac{\text { hasil benar }}{\text { jumlah data }} x 100 \%$ 


$$
\text { hasil pengujian }=\frac{99}{105} \times 100 \%=94 \%
$$

Table 6. Hasil perbandingan pengujian prediksi

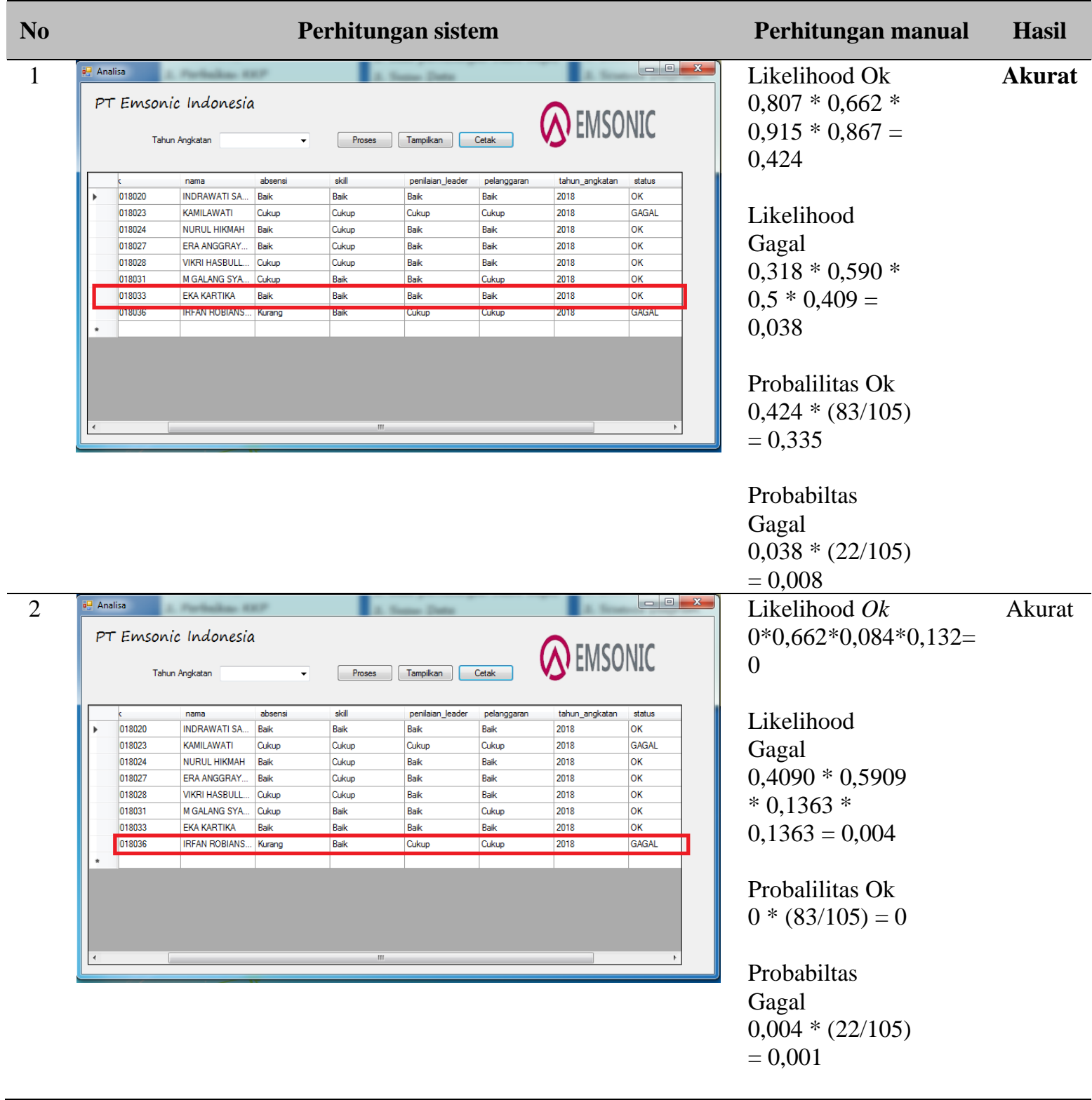

Berdasarkan poin 1 diketahui bahwa perhitungan naïve bayes maka dapat disimpulkan bahwa hasil input status karyawan adalah Ok karena nilai probabilitas tertinggi adalah Ok yaitu 0,335. Sedangkan untuk poin 2, hasil input status karyawan adalah Gagal karena nilai probabilitas tertinggi adalah Gagal dengan nilai 0,001 .

Apabila peneliti analisis, maka ddapat diketahui bahwa:

1. Sistem dapat menghasilkan prediksi sesuai dengan yang diharapkan

2. Sistem dapat memproses sekaligus memprediksi berdasarkan tahun angkatan, sehingga tidak memerlukan proses satu persatu

3. Hasil prediksi dapat digunakan sebagai alat pengambil keputusan Sedangkan kekurangan dari sistem ini yaitu hasil prediksi tidak dapat dihapus sehingga sebelum melakukan proses perlu memastikan data testing sudah benar. 


\section{KESIMPULAN}

Berdasarkan penelitian yang telah dilakukan oleh peneliti dapat disimpulkan bahwa algoritma navie bayes dapat digunakan untuk memprediksi status karyawan berdasarkan penilaian dan data sebelumnya sehingga dapat menjadi referensi dalam menentukan status karyawan. Sedangkan akurasi yang dihasilkan sebesar 94\% dengan kesalahan hanya 6 data.

\section{DAFTAR PUSTAKA}

[1] E. Afrianti, F. Fathoni, and R. I. Heroza, "Klasifikasi Teks dengan Naïve Bayes Classifier (NBC) untuk Pengelompokan Keterangan Laporan dan Durasi Recovery Time Laporan Gangguan Listrik PT.PLN (Persero) WS2JB Area Palembang," JSI J. Sist. Inf., vol. 12, no. 1, pp. 1955-1961, 2020.

[2] F. Handayani and F. S. Pribadi, "Implementasi Algoritma Naive Bayes Classifier dalam Pengklasifikasian Teks Otomatis Pengaduan dan Pelaporan Masyarakat melalui Layanan Call Center 110," J. Tek. Elektro, vol. 7, no. 1, pp. 19-24, 2015, doi: 10.15294/jte.v7i1.8585.

[3] S. Adi, "Implementasi Algoritma Naive Bayes Classifier untuk Klasifikasi Penerima Beasiswa PPA di Universitas AMIKOM Yogyakarta," J. Mantik Penusa, vol. 22, no. 1, pp. 11-16, 2018.

[4] V. M. M. Siregar, "Sistem Pendukung Keputusan Penentuan Insentif Bulanan Pegawai dengan Menggunakan Metode Naive Bayes," SISTEMASI, vol. 7, no. 2, pp. 87-94, 2018, doi: https://doi.org/10.32520/stmsi.v7i2.287.

[5] G. Gustientiedina, M. Siddik, and Y. Desnelita, "Penerapan Naïve Bayes untuk Memprediksi Tingkat Kepuasan Mahasiswa Terhadap Pelayanan Akademis," $J$. Infomedia, vol. 2, no. 4, pp. 2-6, 2019, doi: http://dx.doi.org/10.30811/jim.v4i2.1892.

[6] I. Anggraini, Y. N. Kunang, and F. Firdaus, "Penerapan Naive Bayes pada Pendeteksian Malware dengan Diskritisasi Variabel," Telematika, vol. 13, no. 1, pp. 11-21, 2020, doi: http://dx.doi.org/10.35671/telematika.v13i1.886.

[7] R. Y. Hayuningtyas, "Penerapan Algoritma Naïve Bayes untuk Rekomendasi Pakaian Wanita," J. Inform., vol. 6, no. 1, pp. 18-22, 2019, doi: 10.31311/ji.v6i1.4685.

[8] Y. Yuliyana and A. S. R. M. Sinaga, "Sistem Pakar Diagnosa Penyakit Gigi Menggunakan Metode Naive Bayes," Fountain Informatics J., vol. 4, no. 1, p. 19, 2019, doi: $10.21111 /$ fij.v4i1.3019.

[9] A. Saleh, "Implementasi Metode Klasifikasi Naïve Bayes Dalam Memprediksi Besarnya Penggunaan Listrik Rumah Tangga," Creat. Inf. Technol. J., vol. 2, no. 3, pp. 207-217, 2015, doi: https://doi.org/10.24076/citec.2015v2i3.49.

[10] S. Riyadi, "Penerapan Metode Naive Bayes dalam Pengklasifikasian Trafik Jaringan," smatika, vol. 53, no. 9, pp. 1689-1699, 2013, doi: https://doi.org/10.32664/smatika.v6i02.45. 